\title{
High levels of circulating folate concentrations are associated with DNA methylation of tumor suppressor and repair genes $p 16, M L H 1$, and MGMT in elderly Chileans
}

Hugo Sanchez ${ }^{1}$, Mohammad B. Hossain², Lydia Lera', Sandra Hirsch ${ }^{4}$, Cecilia Albala', Ricardo Uauy ${ }^{1}$, Karin Broberg ${ }^{2,3}$ and Ana M. Ronco ${ }^{4^{*}}$

\begin{abstract}
Background: Changes in DNA methylation, one of the most studied epigenetic mechanisms, are considered an initial marker for early cancer detection. We evaluated how availability of dietary factors (folates and vitamin B12) involved in one-carbon metabolism may contribute to DNA methylation changes of cancer-related genes in human subjects.

Methods: We studied, by pyrosequencing, the methylation of tumor suppressor gene p16, DNA repair genes MLH1 and MGMT, and the repetitive element LINE-1 (as a surrogate for global DNA methylation), in blood of elderly individuals $(n=249$ ) who had been exposed to folic acid (FA) through FA-fortified wheat flour during the last 12 years.
\end{abstract}

Results: We found that serum folate and to a lesser extent, vitamin B12 concentrations, were significantly correlated with DNA methylation of $p 16, M L H 1$, and MGMT, but not with LINE-1. High serum folate concentrations $(>45.3 \mathrm{nmol} / \mathrm{L}$ ) were present in $31.1 \%$ of the participants. Although the methylated fraction of CpG sites in $p 16$, $M L H 1$, and MGMT was low (1.17-3.8\%), high folate concentrations were significantly associated with methylation at the 3rd tertile of specific CpG sites in all genes with OR between 1.97 and 4.17.

Conclusions: This study shows that a public policy, like food fortification with FA that increases circulating serum folate levels, could affect methylation levels of specific genes linked to cancer risk. Our present results deserve additional studies to clarify the real impact of high FA levels for risk of cancer in a whole population chronically exposed to a fortified food such as wheat flour.

Trial registration: ISRCTN 48153354 and ISRCTN 02694183

Keywords: Folates, DNA methylation, Tumor suppressor genes

\footnotetext{
* Correspondence: amronco@inta.uchile.cl

${ }^{4}$ Unidad de Nutrición Humana, Instituto de Nutrición y Tecnología de los

Alimentos Doctor Fernando Monckeberg Barros (INTA), Universidad de Chile,

Santiago, Chile

Full list of author information is available at the end of the article
} 


\section{Background}

Folates are hydrosoluble vitamins naturally present in foods. Folates are essential during pregnancy due to their role in prevention of neural tube defects and in many physiological functions, including cell proliferation and differentiation processes, DNA replication, angiogenesis, methylation reactions through the one-carbon metabolism, and antioxidant protection [1]. Due to the essentiality of folates during pregnancy, several countries have implemented fortification programs with folic acid (FA), the oxidized synthetic compound used in dietary supplements and food fortification. Chile started the fortification program in 2000 with $220 \mu \mathrm{g}$ of FA/100 g of wheat flour, which led to a $40 \%$ decrease in the prevalence of neural tube diseases (NTD) 6 years later [2]. However, this public policy has increased folate consumption across the whole population, since bread is one of the most consumed foods in Chile [3]. In previous work, we have detected that $30 \%$ of the elderly people register circulating levels of folates higher than $48 \mathrm{nmol} / \mathrm{L}[4,5]$, slightly higher than the upper physiological reference value of $45.3 \mathrm{nmol} / \mathrm{L}$ described for adults [6]. Some years ago, it was suggested that FA flour fortification masked vitamin B12 (Vit B12) deficiency found in elderly people $[4,5]$; this evidence led to the health authorities to supplement elderly population with this vitamin [7]. Vit B12 is required for one-carbon metabolism and plays a key role in maintaining central and peripheral nervous system function [8]. Low Vit B12 status occurs more frequently in older adults, and its global deficit in this group ranges from 7 to $51 \%[5,9]$. Low Vit B12 concentration combined with high serum folates has been associated with increased risk of anemia, cognitive impairment, and neuroconduction alterations in older adults $[10,11]$.

Several biological functions of folates and Vit B12 are related with their participation in the one-carbon cycle that produces methyl groups for various processes in the body, such as DNA methylation, one of the key epigenetic processes in vertebrates [12]. Epigenetic regulation plays a critical role in normal growth and embryonic development by controlling the transcriptional activities of several genes [13]. A growing number of epigenetic changes have been reported in the regulation of key genes involved in cancer and aging [14]. DNA methylation changes seem to be an early event in tumorigenesis and have therefore been proposed as potential markers for early cancer detection [15]. Accumulating evidence indicates that DNA methylation markers in the stool and blood samples would provide a minimally invasive tool for colorectal cancer screening [16]. For this reason, an elevated intake of folates, mainly as FA, whose absorption in the gastrointestinal tract is not saturable, may lead to aberrant DNA methylation in cancer genes and may be not safe [17].
The Long Interspersed Nuclear Element 1 (LINE-1) retrotransposable elements make up about $17 \%$ of human DNA, and the methylation status of $L I N E-1$ is often used as a proxy for global DNA methylation [18]. The CpG sites in LINE-1 are usually heavily methylated and genome-wide loss of methylation from these sites has been regarded as a common epigenetic event in malignancy [19]. The $p 16$ tumor suppressor gene is found altered in a wide range of human cancers like endometrial carcinoma, hepatic, gastric, and colorectal cancer [20-22], and it has been suggested as a biomarker for colorectal cancer [23]. It encodes a specific inhibitor of cyclin-dependent kinase 4 and 6 and plays a pivotal role in tumor suppressor networks through inducing cellular senescence that acts as a barrier to cellular transformation by oncogenic signals [24]. Also, p16 loses its expression mainly by the hypermethylation of its promoter $[20,21]$. Methylated $p 16$ gene in blood may serve as a potential biomarker for cancer progression and a prognostic factor for several types of cancer [21].

MLH1 promoter methylation has been implicated in the development of gastric and colorectal cancer; detection of MLH1 methylation in non-neoplastic gastric epithelia may be useful for screening patients who may be at risk of developing gastric cancer [25]. $M L H 1$ is an important component in the mismatch repair system [26], and a recent review highlighted the importance of epigenetic inactivation of $M L H 1$ gene in colorectal cancer [27]. Also, MGMT is crucial for genome stability. It repairs the naturally occurring mutagenic DNA lesion and prevents mismatch and errors during DNA replication and transcription. A meta-analysis involving 14 studies showed that the frequency of MGMT methylation was significantly higher in colorectal cancer than in normal tissues [28].

We have considered the chance that the increased incidence of colon cancer observed in Chile in the last years may be related with a high intake of FA due to food fortification with FA [29]. However, to date, there is no enough evidence to associate high FA consumption with cancer.

This report is a cross-sectional study aimed at evaluating epigenetic effects of high folate serum concentrations along with low, normal, or high Vit B12 serum concentrations on cancer-related genes and repetitive DNA sequences. The study was conducted in an elderly population in Chile who has been exposed to FA through fortified wheat flour during the last 12 years. We hypothesized that subjects with higher circulating concentrations of folates had increased levels of methylation in the tumor suppressor genes, to contribute with additional evidence related to the association between FA supplementation and colon cancer. 


\section{Methods}

\section{Subjects}

We included elderly Chileans that were enrolled for a larger randomized controlled study in Santiago, Chile. The detail of the protocol was published previously [30]. The elderly were apparently healthy, free living, and beneficiaries of a complementary feeding program for older people above 65 years (called PACAM) [31]. Exclusion criteria were as follows: severe cognitive impairment (Mini-Mental State Examination score <19 points [32]); diabetes type 2 (fasting glucose concentrations $\geq 126 \mathrm{mg}$ / $\mathrm{dL}$, insulin, or use of other medications for diabetes), advanced renal impairment (creatinine clearance $\leq 30 \mathrm{mg}$ / $\mathrm{mL}$ ); hypothyroidism ( $\mathrm{TSH}$ concentration $\geq 6 \mathrm{mIU} / \mathrm{L}$ ); gastrointestinal surgery; alcohol abuse based on reported daily consumption; or a clinical history of stroke.

Participants of the study had been exposed to FA through fortification of wheat flour during the last 12 years since Chile started the nation-wide fortification program in the year 2000. Blood samples were collected and stored for blood measurements and DNA extraction. Ethics committees at the Institute of Nutrition and Food Technology (INTA) of the University of Chile and the Ministry of Health (Government of Chile) approved the study. All participants provided full written informed consent before being enrolled in the study and approved a consent to publish results.

\section{Analyses in blood}

Serum concentrations of folates, Vit B12, methyl malonic acid (MMA), and holotranscobalamin (HoloTC) were measured. MMA and HoloTC were used as sensitive tests for early or mild vitamin B12 deficiency. Total homocysteine (tHcy) in plasma was used as an indirect indicator of folate, vitamin B12, and B6 deficiency. Serum Vit B12 and folate concentrations were assessed in duplicate with the use of the SimulTRAC_SNB radioassay kit (57Co/Folate125I; MP Diagnostics) (coefficient of variance (CV) 15-20\%) [11]. Serum MMA was analyzed with the use of ultraperformance liquid- chromatography-tandem mass spectrometry [33](CV $5 \%)$. Serum HoloTC was determined with the AxisShield HoloTC ELISA (Axis-Shield Diagnostics Ltd.) (CV 10\%), and plasma tHcy was determined by HPLC with a fluorescence detector (Agilent 1200; Agilent) (CV 10-15\%).

All serum and plasma markers were measured at the Department of Agriculture, Agricultural Research Services, Western Human Nutrition Research Center, Davis, CA, USA.

\section{DNA isolation and methylation analysis}

DNA was isolated from whole blood by DNeasy Blood \& Tissue kit (Qiagen) and quantified by Qubit dsDNA BR kit (Life Technologies) by the NanoQuant Infinite M200Pro (Tecan). DNA integrity was checked by agarose gels stained by ethidium bromide. Four hundred nanograms of DNA (20 ng/ $\mu \mathrm{L}$ ) was bisulfite-treated using EZ DNA Methylation kit (Zymo Research, catalog number D5008). Bisulfite treatment converts unmethylated cytosine into uracil residues, leaving the methylated cytosine unchanged. The bisulfite-treated DNA was stored at $-20{ }^{\circ} \mathrm{C}$ until used in PCR. We verified bisulfite conversion using non-CpG cytosine residues as built-in controls, and complete conversion of cytosine at a non-CpG site indicated successful bisulfite conversion.

We studied, by pyrosequencing, the methylation of tumor suppressor genes (Fig. 1). PCR and pyrosequencing: bisulfite-treated DNA $(0.6 \mu \mathrm{L})$ was used in a $15-\mu \mathrm{L}$ PCR reaction using the Pyromark PCR kit (Qiagen). One of the PCR primers was biotinylated. The PCR product was purified using Streptavidin Sepharose High Performance beads (Amersham Biosciences, Uppsala, Sweden). The Sepharose beads containing immobilized PCR products were purified, washed, and denatured with $0.2 \mathrm{M}$ $\mathrm{NaOH}$ and washed again using a vacuum prep tool (Pyrosequencing Inc., Westborough, MA, USA). Twelve microliters of the pyrosequencing primer $(0.3 \mu \mathrm{mol} / \mathrm{L})$ was annealed to the purified single-stranded PCR product,

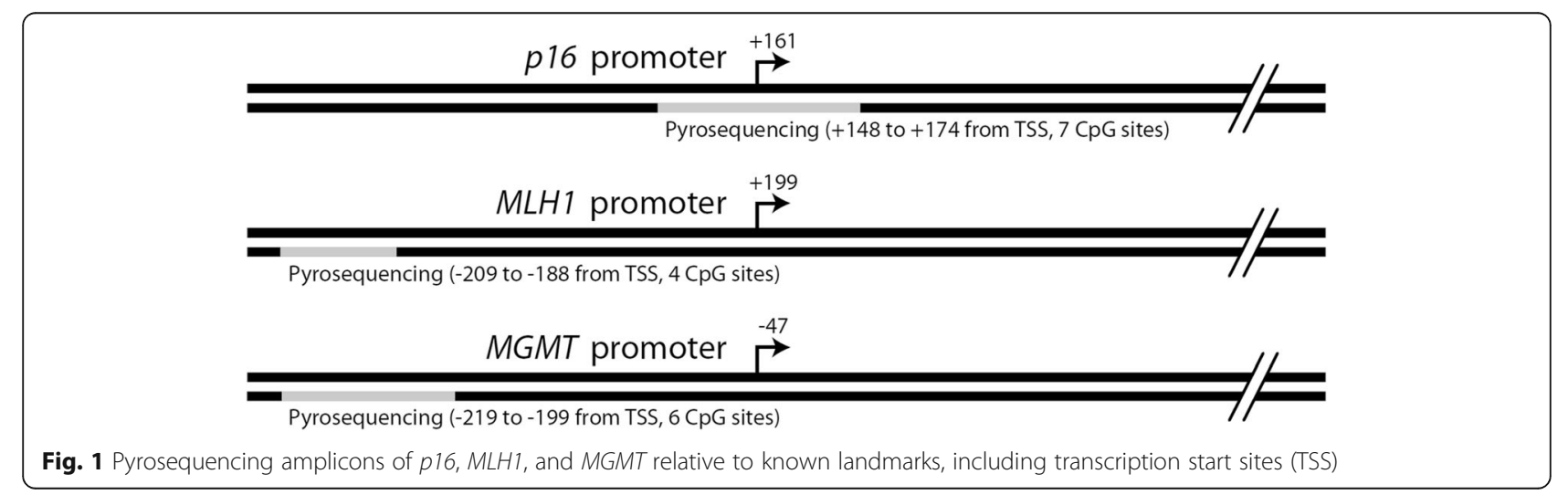


and pyrosequencing was done using the PSQ HS96 Pyrosequencing System (Qiagen).

Commercially available assays (Qiagen) were used to measure the methylation of LINE-1 (four CpG sites between 305 and 331 bp, GenBank accession no. X58075), p16 (seven CpG sites between +148 and +174 bp around the transcription start site in exon 1; L27211), and MLH1 (4 CpG sites between -209 to -188 bp from transcription start site; U07418) following the manufacturer's instruction [34, 35]. To determine the methylation level of MGMT promoter region, we developed an assay covering six CpG sites $(-219$ to -199 bp from transcription start site based on previous publications [36, 37], ENSG00000170430). The assay was designed by PyroMark Assay Design 2.0 software (Qiagen). The sequences of forward, reverse, and sequencing primers are GGTTATTTGGTAAATTAAGGTATAGAGTT, biotin- AACTATCCCAACATATCC, and GTTGTAGGAGGATTAGG, respectively.

We performed extensive quality control for the p16 and $M L H 1$ assays as well as tested for amplification bias [38] and found that both the assays were within recommended range for this type of bias [35].

\section{Statistical analyses}

Continuous variables were expressed as mean \pm SD (standard deviation) and 95\% confidence intervals (95\% CI) or as median (p25-p75) and 95\% CI. Categorical variables were expressed as percentages and 95\% CI. The difference between sexes was calculated by two-sample mean-comparison test, two-sample Wilcoxon rank-sum test or Pearson's $\mathrm{Chi}^{2}$ test, depending on the kind of variables. Spearman correlations were calculated for blood concentrations of vitamins and metabolites and the methylation in specific CpG sites.

We categorized vitamin B12 plasma levels as deficit $(\mathrm{B} 12<148 \mathrm{pmol} / \mathrm{L})$, marginal deficit $(\mathrm{B} 12 \geq 148$ and $<221 \mathrm{pmol} / \mathrm{L})$, and normal (B12 $\geq 221 \mathrm{pmol} / \mathrm{L}$ ) as suggested by Morris et al. [10]. Folates were categorized using the cut off points suggested by Pfeifer (as supra physiologic folate level $\geq 45.3 \mathrm{nmol} / \mathrm{l}$ ) [6]. A logistic regression served to analyze the association between Vit B12 and folate and the percentage of methylation in specific $\mathrm{CpG}$ sites. CpG methylation was categorized in tertiles being the 3rd tertile the most methylated [26]. These results were adjusted by age, sex, body mass index (BMI), tobacco, and vitamin metabolites (HoloTC, tHcy, and MMA). We considered that tumor suppressor and DNA repair-related genes would be highly expressed thus conferring protection from risk of cancer. All statistical analyses were performed using STATA 14 software (StataCorp. 2015. Stata Statistical Software, Release 14. College Station, TX, StataCorp LP).
Table 1 Characteristics of subjects

\begin{tabular}{|c|c|c|c|}
\hline & $\begin{array}{l}\text { Men } \\
(n=77)\end{array}$ & $\begin{array}{l}\text { Women } \\
(n=172)\end{array}$ & $\begin{array}{l}\text { Total } \\
(n=249)\end{array}$ \\
\hline \multicolumn{4}{|l|}{$\overline{\text { Age } \text { (years) }^{a}}$} \\
\hline mean $\pm S D$ & $73.5 \pm 2.7$ & $73.9 \pm 3.1$ & $73.8 \pm 3.0$ \\
\hline $95 \% \mathrm{Cl}$ & $72.9-74.1$ & $73.5-74.4$ & $73.4-74.2$ \\
\hline \multicolumn{4}{|l|}{ Education (years) } \\
\hline median $(p 25-p 75)^{b}$ & $6(4-8)$ & $6(8-3)$ & $6(8-3)$ \\
\hline$\leq 6$ years $\%(n)^{c}$ & $56.6(43)$ & $63.7(107)$ & $61.5(150)$ \\
\hline $95 \% \mathrm{Cl}$ & $44.7-67.9$ & $55.9-71.0$ & $55.1-67.6$ \\
\hline \multicolumn{4}{|c|}{ Medication (number) ${ }^{* * * c}$} \\
\hline $0, \%(n)$ & $23.4(18)$ & $11.1(19)$ & $14.9(37)$ \\
\hline $95 \% \mathrm{Cl}$ & $14.5-34.4$ & $6.8-16.7$ & $10.7-19.9$ \\
\hline $1, \%(n)$ & $19.5(15)$ & $10.5(18)$ & $13.3(33)$ \\
\hline $95 \% \mathrm{Cl}$ & $11.3-30.1$ & $6.3-16.0$ & $9.3-18.1$ \\
\hline $2-3, \%(n)$ & $36.4(28)$ & $34.9(60)$ & $35.3(88)$ \\
\hline $95 \% \mathrm{Cl}$ & $25.7-48.1$ & $27.8-42.5$ & $29.4-41.6$ \\
\hline $4+, \%(n)$ & $20.8(16)$ & $43.6(75)$ & $36.6(91)$ \\
\hline $95 \% \mathrm{Cl}$ & $12.4-31.5$ & $36.1-51.4$ & $30.5-42.9$ \\
\hline \multicolumn{4}{|l|}{ MMSE $^{* b}$} \\
\hline median (p25-p75) & $28(26-29)$ & $27(25-29)$ & $27(25-29)$ \\
\hline \multicolumn{4}{|l|}{$\left.B M\right|^{* a}$} \\
\hline $\mathrm{BM}{ }^{* a}$ mean $\pm S D$ & $26.9 \pm 3.2$ & $28.5 \pm 5.1$ & $28.1 \pm 4.7$ \\
\hline $95 \% \mathrm{Cl}$ & $26.2-27.7$ & $27.7-29.3$ & $27.4-28.6$ \\
\hline \multicolumn{4}{|c|}{ Tobacco consumption ${ }^{* * c}$} \\
\hline$\%(n)$ & $10.5(8)$ & $5.8(10)$ & $7.3(18)$ \\
\hline Cl 95\% & $4.6-19.4$ & $2.8-10.4$ & $4.3-11.2$ \\
\hline
\end{tabular}

Medications frequently used in elderly: antihypertensive, anti-inflammatory, antidepressant

$B M I$ Body Mass Index, MMSE Minimental state examination

${ }^{*} p<0.05 ;{ }^{* *} p<0.01 ;{ }^{* * *} p<0.001$

aTwo-sample mean-comparison test

${ }^{\mathrm{b}}$ Two-sample Wilcoxon rank-sum test

'Pearson's Chi ${ }^{2}$ test

\section{Results}

Subjects

Descriptive data for the participants are shown in Table 1. The subjects were a representative sample of the respective age group within the population of low socio economic level elderly Chileans [9] with a relatively low education level (median 6 years); no sex differences were noted. Women consumed twice as much antidepressant and antihypertensive drugs than men $(p<0.001)$. Cognitive status assessed by the Mini Mental State Examination (MMSE) [32] was lower in women than in men; however, that difference was clinically irrelevant; men and women had scores within the accepted normal range for age (MMSE $\geq 21$ $22)$. BMI was slightly higher in women than in men $(p<0.05)$. Smoking rates was low in the participants and however higher in men compared to women $(p<0.05)$. 
Table 2 DNA methylation in specific CpG sites

\begin{tabular}{|c|c|c|c|c|}
\hline Genes & CpG site & Men $(n=77)$ & Women $(n=172)$ & Total $(n=249)$ \\
\hline \multirow[t]{5}{*}{ LINE-1 } & 1 & $86.2(84.5-86.9)$ & $85.75(84.5-86.9)$ & $85.8(84.8-86.7)$ \\
\hline & 2 & 82.6 (82.3-82.8) & 82.5 (82.2-82.8) & $82.5(82.3-82.7)$ \\
\hline & 3 & $80.875(80.4-81.75)$ & 80.9 (80.3-81.3) & $80.9(80.5-81.2)$ \\
\hline & 4 & $82.2(81.3-83.2)$ & $82.0(81.6-82.4)$ & $82.0(81.7-82.4)$ \\
\hline & Average & 83.3 (82.8-83.8) & $82.8(82.6-83.3)$ & $82.9(82.65-83.4)$ \\
\hline \multirow[t]{8}{*}{ p16 } & 1 & $3.36(3.0-3.89)$ & $3.46(3.25-3.64)$ & $3.44(3.25-3.6)$ \\
\hline & 2 & $1.575(1.16-1.9)$ & $1.58(1.45-1.87)$ & $1.58(1.46-1.79)$ \\
\hline & 3 & $1.88(1.37-2.12)$ & $1.84(1.62-2.07)$ & $1.85(1.66-2.04)$ \\
\hline & $4^{*}$ & $2.2(1.91-2.25)$ & $1.88(1.75-2.05)$ & $1.96(1.82-2.11)$ \\
\hline & 5 & $0.91(0-1.60)$ & $1.65(1.41-1.92)$ & 1.49 (1.34-1.77) \\
\hline & 6 & 0 & 0 & 0 \\
\hline & 7 & $1.89(1.38-2.23)$ & $1.94(1.73-2.12)$ & $1.91(1.71-2.09)$ \\
\hline & Average & $1.89(1.66-2.06)$ & $1.92(1.78-2.02)$ & 1.907 (1.79-2.01) \\
\hline \multirow[t]{5}{*}{ MLH1 } & 1 & $0(0-0.99)$ & 0 & 0 \\
\hline & 2 & $1.39(0-2.35)$ & $1.82(0-2.10)$ & $1.725(0-2.07)$ \\
\hline & 3 & 0 & 0 & 0 \\
\hline & $4^{\gamma}$ & $2.3(1.75-2.80)$ & $2.495(1.96-2.84)$ & $2.435(1.97-2.77)$ \\
\hline & Average & $1.25(0.70-1.38)$ & $1.12(0.74-1.31)$ & $1.165(0.81-1.31)$ \\
\hline \multirow[t]{7}{*}{ MGMT } & 1 & $3.345(2.53-4.21)$ & $4.01(3.51-4.66)$ & $3.8(3.41-4.26)$ \\
\hline & 2 & $0(0-1.65)$ & $0(0-1.88)$ & 0 \\
\hline & 3 & 0 & 0 & 0 \\
\hline & 4 & $1.865(1.38-2.31)$ & $1.87(1.61-2.26)$ & $1.87(1.61-2.15)$ \\
\hline & 5 & 0 & 0 & 0 \\
\hline & 6 & 0 & 0 & 0 \\
\hline & Average & $1.555(1.10-2.11)$ & 1.72 (1.39-1.87) & $1.66(1.44-1.87)$ \\
\hline
\end{tabular}

Results are expressed as percentages of methylation and $95 \% \mathrm{Cl}$. Two-sample Wilcoxon rank-sum test ${ }^{*} p=0.04 ;{ }^{\gamma} p=0.07$; for other results $p>0.1$

\section{Methylation of genes}

Table 2 describes DNA methylation for all genes studied as the percentage of methylation. We observed high methylation of LINE-1 sequences, as expected [39]. In general, the percentage of methylation of the tumor suppressor and DNA repair genes studied were low (1.1 to $4.17 \%)$, suggesting that these genes were highly expressed [40]. No differences related with sex were observed in methylation status.

\section{Blood determinations}

The concentrations of vitamins in serum are shown in Table 3. Deficient concentrations of Vit B12 ( $<148$ pmol/ L) were present in $11.1 \%$ of the participants while $78.4 \%$ showed Vit B12 concentrations $\geq 221 \mathrm{pmol} / \mathrm{L}$, with $29 \%$ of them having high Vit B12 concentrations ( $>680 \mathrm{pmol} / \mathrm{L}$ ). It is likely that these subjects were taking vitamin supplements. HoloTC was higher in women than in men $(p=0.029)$, although HoloTC concentrations in both men and women were within the normal range (40-200 pmol/ L) [41]. MMA concentrations were within the normal range indicate Vit B12 deficiency (MMA $\leq 400 \mathrm{nmol} / \mathrm{L}$ ) [42]. Serum folate concentrations were $36 \mathrm{nmol} / \mathrm{L}$ (median; p25-p75 = 24-253.8) slightly higher in women compared with men $(p=0.0499)$. Interestingly, $31.1 \%$ of the participants showed high serum folate concentrations ( $>45.3 \mathrm{nmol} / \mathrm{L}$ ): $34.1 \%$ of women compared with $24.3 \%$ of men $(p=0.031)$. Homocysteine levels were within normal reference range $(<15 \mu \mathrm{mol} / \mathrm{L})[43]$ without sex differences.

\section{Analysis of correlations and regression models}

Table 4 shows correlations between the vitamins and DNA methylation in studied genes. No correlation was found between vitamins and methylation in LINE-1. Vit B12 and folates correlated with DNA methylation in specific CpG sites of p16, MGMT, and MLH1 genes. For p16, Vit B12 was positively correlated with DNA methylation in $\mathrm{CpG} 1,3$, and 5 and with average methylation, and folates correlated positively with $\mathrm{CpG}$ sites 3 and 5 . For $M L H 1$, Vit B12 correlated negatively with methylation of $\mathrm{CpG}$ site 1, and folates correlated positively with CpG 2, 4 and average $M L H 1$ methylation. For $M G M T$, 
Table 3 Blood level of vitamins and metabolites

\begin{tabular}{|c|c|c|c|}
\hline & $\begin{array}{l}\text { Men } \\
(n=66)\end{array}$ & $\begin{array}{l}\text { Women } \\
(n=142)\end{array}$ & $\begin{array}{l}\text { Total } \\
(n=208)\end{array}$ \\
\hline $\begin{array}{l}\text { Vitamin B12 (pmol/L) Median } \\
\text { (p25-p75) }\end{array}$ & $\begin{array}{l}370.7 \\
(221.9-683.0)\end{array}$ & $\begin{array}{l}438.5 \\
(215.4-767.5)\end{array}$ & $\begin{array}{l}409.3 \\
(218.8-729.3)\end{array}$ \\
\hline $\begin{array}{r}<148 \mathrm{pmol} / \mathrm{L} \%(n) \\
(95 \% \mathrm{Cl})\end{array}$ & $\begin{array}{l}10.6(7) \\
(4.4-20.6)\end{array}$ & $\begin{array}{l}11.3(16) \\
(6.6-17.7)\end{array}$ & $\begin{array}{l}11.1(23) \\
(7.1-16.1)\end{array}$ \\
\hline $\begin{array}{r}148-221 \mathrm{pmol} / \mathrm{L} \%(n) \\
(95 \% \mathrm{Cl})\end{array}$ & $\begin{array}{l}12.1(8) \\
(5.4-22.5)\end{array}$ & $\begin{array}{l}9.9(14) \\
(5.5-16)\end{array}$ & $\begin{array}{l}10.6(22) \\
(6.7-15.6)\end{array}$ \\
\hline $\begin{array}{r}>221 \mathrm{pmol} / \mathrm{L} \%(n) \\
(95 \% \mathrm{Cl})\end{array}$ & $\begin{array}{l}77.3(51) \\
(65.3-86.7)\end{array}$ & $\begin{array}{l}78.9(112) \\
(71.2-85.3)\end{array}$ & $\begin{array}{l}78.4(163) \\
(72.1-83.8)\end{array}$ \\
\hline $\begin{array}{l}\text { MMA (nmol/L) Median } \\
\text { (p25-p75) }\end{array}$ & $\begin{array}{l}187 \\
(145-247)\end{array}$ & $\begin{array}{l}177.5 \\
(143-269)\end{array}$ & $\begin{array}{l}180 \\
(143-266)\end{array}$ \\
\hline $\begin{array}{l}\text { HoloTC (pmol/L) Median } \\
\text { (p25-p75) }\end{array}$ & $\begin{array}{l}67.7 \\
(46.8-121.3)\end{array}$ & $\begin{array}{l}102.9^{* *} \\
(56-171.3)\end{array}$ & $\begin{array}{l}180 \\
(143-266)\end{array}$ \\
\hline $\begin{array}{l}\text { Folates (nmol/L) Median } \\
\text { (p25-p75) }\end{array}$ & $\begin{array}{l}34.6 \\
(20.3-44.9)\end{array}$ & $\begin{array}{l}36.6^{*} \\
(25.3-61.5)\end{array}$ & $\begin{array}{l}36 \\
(24.253 .8)\end{array}$ \\
\hline $\begin{array}{r}>45.3 \mathrm{nmol} / \mathrm{L} \%(n) \\
(95 \% \mathrm{Cl})\end{array}$ & $\begin{array}{l}24.3(18) \\
(15.1-35.7)\end{array}$ & $\begin{array}{l}34.1(57)^{\gamma} \\
(27.0-41.9)\end{array}$ & $\begin{array}{l}31.1(75) \\
(25.3-37.4)\end{array}$ \\
\hline $\begin{array}{l}\text { Homocysteine ( } \mu \mathrm{mol} / \mathrm{L}) \text { Median } \\
\text { (p25-p75) }\end{array}$ & $\begin{array}{l}11.3 \\
(9.3-12.7)\end{array}$ & $\begin{array}{l}10.6 \\
(8.7-13.2)\end{array}$ & $\begin{array}{l}10.8 \\
(8.7-13.1)\end{array}$ \\
\hline
\end{tabular}

Results are expressed as median (p25-p75) and \% (n) and 95\% Cl

MMA methylmalonic acid, HoloTC holotranscobalamin

${ }^{*} p=0.0499$, two-sample Wilcoxon rank sum test; ${ }^{*} p=0.029 ;{ }^{\gamma} p=0.031, \mathrm{Chi}^{2}$ test

Vit B12 correlated positively with CpG 2, and folates correlated positively with methylation of CpG sites 1-3 and average and negatively with CpG4. Concentrations of HoloTC, Hcy, and MMA did not correlate with methylation in the DNA of any studied gene.

A logistic regression model (Table 5) was used to evaluate possible associations between high folate $(>45.3 \mathrm{nmol} / \mathrm{L})$ and low Vit B12 concentrations $(<148$ and between $148<221 \mathrm{pmol} / \mathrm{L}$ ) with DNA methylation of tumor suppressor and repair genes above the 3rd tertile that might lead to a lower expression. For $p 16$, folate concentrations $>45.3 \mathrm{nmol} / \mathrm{L}$ were significantly associated with risk of increased DNA methylation of CpG sites 3 and 5, with an OR of 1.97 and 4.17, respectively (Table 5). For $M L H 1$, high folate level was significantly associated with risk of increased mean DNA methylation (OR: 2.2) and also to increased DNA methylation of CpG sites 1-3 (OR: 2.31, 3.73, and 2.08, respectively) (Table 5). For MGMT, high folate level was associated risk of increased average DNA methylation (OR: 2.84) and increased DNA methylation of CPG site 4 (OR: 3.91). No significant associations were observed between low Vit B12 $(<148 \mathrm{nmol} / \mathrm{L})$ and DNA methylation.

\section{Discussion}

In this study, we found that about one third of the participants, who have been exposed to FA during 12 years through wheat flour fortification, show a mean circulating folate concentrations higher than $45.3 \mathrm{nmol} / \mathrm{L}$, described as supra physiological [6]. More women than men registered supra physiological folate concentrations $(p<0.031)$. Also, circulating folate concentrations were slightly higher in women than in men $(p<0.0499)$. These results demonstrate that there is probably no folate deficiency in the Chilean population, including the elderly, which may be a consequence of the mandatory public policy of fortifying wheat flour with FA to prevent neonates NTD initiated in Chile the year 2000 [2]. Other important finding is that high serum folate levels increase DNA methylation of tumor suppressor genes $p 16$ and DNA repair genes MLH1 and MGMT in blood. Folate concentrations $>45.3 \mathrm{nmol} / \mathrm{L}$ increased the risk of methylation in the 3rd tertile in specific $\mathrm{CpG}$ sites of the genes p16 (CpG 5, OR = 4.17), MLH1 (CpG 2, $\mathrm{OR}=3.73)$, and MGMT (CpG4, OR = 3.91). Also, high folate concentrations increased the risk of methylation in the average DNA methylation of MGMT and MLH1.

Due to the essentiality of folates during pregnancy, and to prevent NTD in newborns, several countries, including Chile, started food FA fortification programs to cover requirements of the target population $(600 \mu \mathrm{g} /$ day). However, this policy has led to elevate blood levels of the whole population; estimations are that 20 to $30 \%$ of the general population present serum folate concentrations over $40 \mathrm{nmol} / \mathrm{L}$ [29]. Previous studies found a high incidence of Vit B12 deficiency in elderly Chilean, and it was suggested that those deficiency was masked by high folate levels as a consequence of the food fortification policy of with folates $[4,5]$. This evidence led to the Health Ministry of the Chilean government to 
Table 4 Spearman correlation for blood concentrations of vitamins and metabolites and DNA methylation in specific CpG sites of LINE-1, p16, MLH1, and MGMT genes

\begin{tabular}{|c|c|c|c|c|c|c|}
\hline & CpG site & Vit B12 $n=242$ & Folates $n=241$ & HoloTC $n=193$ & $\operatorname{Hcy} n=193$ & MMA $n=193$ \\
\hline \multirow[t]{5}{*}{ LINE-1 } & 1 & -0.1064 & 0.0193 & -0.1357 & 0.0509 & 0.0298 \\
\hline & 2 & -0.0106 & -0.1259 & -0.0680 & -0.0811 & 0.1004 \\
\hline & 3 & 0.1067 & 0.0360 & 0.1321 & -0.0644 & -0.0318 \\
\hline & 4 & -0.0346 & -0.0127 & -0.1313 & 0.0281 & 0.0394 \\
\hline & Average & -0.0373 & 0.0302 & -0.1135 & 0.0604 & 0.0166 \\
\hline \multirow[t]{7}{*}{ p16 } & 1 & $0.1888^{*}$ & 0.0156 & 0.1152 & -0.0002 & -0.0137 \\
\hline & 2 & -0.0552 & -0.1519 & 0.0104 & -0.0239 & -0.0303 \\
\hline & 3 & $0.2965^{*}$ & $0.2320^{*}$ & 0.1137 & -0.1293 & -0.1288 \\
\hline & 5 & $0.2198^{*}$ & $0.2974^{*}$ & 0.0595 & -0.0462 & -0.1619 \\
\hline & 6 & -0.1668 & -0.1787 & -0.0167 & 0.0709 & 0.0449 \\
\hline & 7 & 0.0863 & -0.1029 & 0.1230 & 0.0455 & -0.0597 \\
\hline & Average & $0.2288^{*}$ & 0.0867 & 0.1553 & -0.0880 & -0.1318 \\
\hline \multirow[t]{5}{*}{ MLH1 } & 1 & $-0.2809^{*}$ & -0.1616 & 0.0360 & -0.0555 & -0.0634 \\
\hline & 2 & 0.0977 & $0.2453^{*}$ & -0.0248 & -0.0422 & -0.0656 \\
\hline & 3 & -0.1404 & -0.1102 & -0.0374 & -0.0393 & -0.0451 \\
\hline & 4 & 0.1246 & $0.3121^{*}$ & 0.0399 & -0.1387 & -0.1486 \\
\hline & Average & -0.1081 & $0.1786^{*}$ & 0.0188 & -0.1410 & -0.1478 \\
\hline \multirow[t]{7}{*}{ MGMT } & 1 & 0.1118 & $0.2291^{*}$ & -0.0167 & -0.0589 & -0.0211 \\
\hline & 2 & $0.3142^{*}$ & $0.4196^{*}$ & -0.0082 & -0.0702 & -0.1504 \\
\hline & 3 & 0.0791 & $0.2007^{*}$ & -0.0522 & -0.0417 & -0.0876 \\
\hline & 4 & -0.1561 & $-0.3457^{*}$ & 0.0002 & 0.0808 & 0.1207 \\
\hline & 5 & -0.1187 & -0.1011 & -0.0570 & -0.0621 & -0.0806 \\
\hline & 6 & -0.0111 & -0.0272 & -0.0012 & -0.1773 & -0.1511 \\
\hline & Average & 0.1168 & $0.2489^{*}$ & -0.0591 & -0.0567 & -0.0474 \\
\hline
\end{tabular}

${ }^{*} p<0.01$

implement a program for older adults, users of the public health system, which provided them periodically with milk or a packaged soup fortified with Vit B12. This may explain that in the present study, only $11.1 \%$ of the participants presented Vit B12 deficiency (Table 3) [7].

Increased circulating folate concentrations have also been considered a risk factor for cardiovascular disease [44] and some forms of cancer [45]. Epidemiologic studies carried out in the USA, Canada [46], and Chile [29] have reported a temporal relationship between mandatory fortification with FA and a greater incidence of colorectal cancer related to the beginning of the fortification programs.

Men with high blood folate levels were at greater risk of high-grade (more aggressive) prostate cancer compared with men with lower folate levels [47]. The Women's Health Initiative Observational Study cohort provided new evidence that increased folate intake during the early post-fortification period may have been associated with a transient increase in colorectal cancer risk [48]. In a population-based study from northern Sweden, a bell-shaped relationship between plasma folate concentrations and colorectal cancer risk was observed, with a doubling of risk for subjects in the middle versus lowest quintile [49].

On the contrary, a recent study with more than 1400 older adults ( $\geq 57$ years) with a median follow-up of 6.3 years showed that high total folate intake appear to be protective against cancer in post-FA fortification years. Those authors did not find significant associations between the presence of non-metabolized FA, intake of naturally-occurring food folate or FA separately, and cancer incidence [50].

Probably, folates like other compounds and vitamins may have a U shape effects, with hazardous effects with both low and high levels.

Folate homeostasis disruption (by high or low levels of folate intake) may change the one-carbon metabolism, the process responsible for production of methyl groups, leading to gene transcription alterations (overexpression 
Table 5 Logistic Regression Model between vitamin B12 and folate levels and the risk of methylation of p16, MLH1, and MGMT at the 3 rd tertile (\%)

\begin{tabular}{|c|c|c|c|c|c|c|}
\hline & & & & \multicolumn{2}{|c|}{ Vit B12 (pmol/L) } & \multirow{2}{*}{$\begin{array}{l}\text { Folates* }(\mathrm{nmol} / \mathrm{L}) \\
>45.3\end{array}$} \\
\hline & & & & $<148$ & $148-221$ & \\
\hline \multirow[t]{4}{*}{ p16 } & \multirow{12}{*}{$\begin{array}{l}\text { CpG } \\
\text { site }\end{array}$} & $3^{a}$ & OR & 0.70 & 0.36 & 1.97 \\
\hline & & & $95 \% \mathrm{Cl}$ & $0.23-2.08$ & $0.10-1.23$ & $1.04-3.75$ \\
\hline & & $5^{b}$ & OR & 0.46 & 0.67 & 4.17 \\
\hline & & & $95 \% \mathrm{Cl}$ & $0.13-1.6$ & $0.2-2.2$ & $2.12-8.19$ \\
\hline \multirow[t]{8}{*}{ MLHI } & & $1^{c}$ & OR & 0.56 & 0.93 & 2.31 \\
\hline & & & $95 \% \mathrm{Cl}$ & $0.14-2.19$ & $0.28-3.13$ & $1.15-4.64$ \\
\hline & & $2^{d}$ & OR & 0.43 & 0.86 & 3.73 \\
\hline & & & $95 \% \mathrm{Cl}$ & $0.10-1.88$ & $0.26-2.90$ & $1.83-7.59$ \\
\hline & & $3^{e}$ & OR & 1.18 & 1.22 & 2.08 \\
\hline & & & $95 \% \mathrm{Cl}$ & $0.34-4.13$ & $0.38-3.95$ & $1.03-4.20$ \\
\hline & & Average $^{f}$ & OR & 0.99 & 1.60 & 2.20 \\
\hline & & & $95 \% \mathrm{Cl}$ & $0.26-3.80$ & $0.48-5.32$ & $1.08-4.50$ \\
\hline \multirow[t]{4}{*}{ MGMT } & & $4^{9}$ & OR & 0.96 & 0.12 & 3.91 \\
\hline & & & $95 \% \mathrm{Cl}$ & $0.28-3.26$ & $0.014-0.99$ & $1.88-8.11$ \\
\hline & & Average $^{h}$ & OR & 0.92 & 0.6 & 2.84 \\
\hline & & & $95 \% \mathrm{Cl}$ & $0.28-2.98$ & $0.19-2.52$ & $1.42-5.69$ \\
\hline
\end{tabular}

Adjusted by sex, age, tobacco, BMI, Hcy, HoloTC, and MMA

$O R$ odd ratio, $\mathrm{Cl}$ confidence interval

${ }^{*} p<0.05$ vs folate $<45.3 \mathrm{nmol} / \mathrm{L}$

${ }^{a}<2.35 \%$ methylation

${ }^{b} 2.11 \%$ methylation

${ }^{c}<5.24 \%$ methylation

${ }^{d}<2.65 \%$ methylation

e $<0.34 \%$ methylation

$\mathrm{f}_{<}<2.14 \%$ methylation

$\mathrm{g}<3.2 \%$ methylation

$\mathrm{h}_{<} 1.48 \%$ methylation

and/or gene silencing) through DNA gene hyper- or hypo-methylation reactions. Disruption of epigenetic processes can in turn lead to altered gene and cell functions leading to malignancy. Recent advancements in the rapidly evolving field of cancer epigenetics have shown extensive reprogramming of every component of the epigenetic machinery in cancer, including DNA methylation [15].

It should be noted that we here analyzed associations between FA and DNA methylation in blood and we do not know if the observed changes in DNA methylation actually are present in the target tissues or associated with cancer incidence. Tumor suppressor genes become inactive with hypermethylation of their promoter regions, and aberrant promoter methylation of tumor suppressor genes is associated with different types of cancers [51] and its serum detection may be a good marker for cancer diagnosis [52]. Recent publications have found that in cervical, colon, breast, bladder, gastric, lung, and esophageal tumors, tumor suppressor genes like $p 15, p 16, p 21, p 27$, $p 57$, and others are hypermethylated in their promoters [53]. Moreover, $p 16$ hypermethylation was found to be an independent prognostic marker for cancer-specific survival. Still, our hypotheses about the effects of folic acid and vitamin $\mathrm{B} 12$ on epigenetic processes in relation to tumor suppressor inactivation warrant further investigation and confirmation in future research following up the cancer incidence among individuals with varying tumor suppressor methylation in blood.

The availability of dietary factors involved in one-carbon metabolism may contribute to aberrant DNA methylation [54]. A recent study on 87 elderly (65-75 years) showed that long-term supplementation of FA and Vit B12 (2 years) resulted in effects on DNA methylation of several genes implicated in carcinogenesis and early embryonic development [55]; genome-wide methylation analysis revealed pronounced methylation changes in the DIRAS3, ARMC8, and NODAL genes. Further, among positions that were differentially methylated after the intervention with FA and Vit B12, CpG positions within CpG islands and around transcription start sites were overrepresented. This suggests that the availability of folate affects DNA methylation at specific DNA regions. Also, other factors that seem to affect DNA methylation, e.g., for p16 
including tobacco, radiation exposure, and pollution, have been associated with aberrant methylation of this gene, and its detection in blood or in serum has been suggested to be a good marker for cancer diagnosis [25]. The percentages of DNA methylation in LINE-1, p16, and MLH1 in the present study are comparable to the methylation levels found in younger Argentinean women exposed to arsenic, although they were on average slightly lower (Argentinean 3.4 vs. Chilean $1.9 \%$ for $p 16$; Argentinean 4.2 vs. Chilean 1.17 [34, 35]. Significant correlation between folates and methylation at specific CpG sites of $p 16$ and $M L H 1$ were different from those linked to arsenic exposure; in this study, we found correlations with methylation of p16 sites 3 and 5 and $M L H 1$ site 4, compared with sites 1 both in $p 16$ and $M L H 1$ associated with arsenic exposure. Stronger correlations were observed for methylation of several sites in MGMT with folates. This suggests that exposure to different compounds may disrupt DNA methylation at different genes and sites.

One limitation of this study is the lack of RNA to assess gene expression and the respective association with the level of DNA methylation, and that we did not follow the cancer incidence in this cohort. However, there is enough information to expect that a hypermethylated gene is less expressed than a hypomethylated gene [56]. A highlight of this study is the homogeneity of the sample, since all of the participants have been exposed to wheat flour fortification with FA.

In summary, we conclude that long time exposure to highly consumed FA-fortified foods by a non-target population increase blood concentrations of circulating folates inducing to a higher risk of higher genespecific methylation levels. Although marginal, the increased methylation levels of tumor suppressor and DNA repair genes may reduce their gene expression that are in turn associated with increased risk of some cancers.

\section{Conclusions}

Elderly Chilean exposed to fortified foods with FA during the last 12 years do not present folate deficiency and have normal or elevated levels of circulating folates. Folate concentrations $>45.3 \mathrm{nmol} / \mathrm{L}$ increased the risk of methylation in specific $\mathrm{CpG}$ sites of tumor suppressor and DNA repair genes.

\footnotetext{
Abbreviations

AF: Folic acid; CV: Coefficient of variance; HoloTC: Holotranscobalamin; LINE1: Long interspersed nuclear element 1; MMA: Methyl malonic acid; MMSE: Mini-Mental State Examination score; NTD: Neural tube disease; OR: Odd ratio; tHcy: Total homocysteine; Vit B12: Vitamin B12
}

Funding

The authors would like to thank Fondo Nacional de Ciencia y Tecnología (FONDECYT), Gobierno de Chile (\#1070592 to RU and \# 1130188 to AMR), and the Swedish Council for Working Life and Social Research FORTE to KB.

\section{Availability of data and materials}

The datasets used and analyzed during the current study are available from the first author $(\mathrm{HS})$ on reasonable request.

\section{Authors' contributions}

$H S, K B$, and $A M R$ contributed to the conception and design of the study. KB, $\mathrm{MBH}, \mathrm{CA}, \mathrm{SH}, \mathrm{RU}$, and $\mathrm{AMR}$ contributed to the major portion of the manuscript writing and editing. $\mathrm{MBH}$ contributed in performing the methylation experiments. $\mathrm{LL}$ and $\mathrm{SH}$ contributed to performing statistical analyses. RU, KB, and AMR contributed in funding. The paper was critically read by all the authors and approved for publication.

\section{Ethics approval and consent to participate}

Ethics committees at the Institute of Nutrition and Food Technology (INTA) of the University of Chile and the Ministry of Health (Government of Chile) approved the study. All participants provided full written informed consent before being enrolled in the study.

\section{Consent for publication}

Consent for publication was obtained from all patients.

\section{Competing interests}

The authors declare that they have no competing interests.

\section{Publisher's Note}

Springer Nature remains neutral with regard to jurisdictional claims in published maps and institutional affiliations.

\section{Author details}

${ }^{1}$ Unidad de Nutrición Pública, Instituto de Nutrición y Tecnología de los Alimentos Doctor. Fernando Monckeberg Barros (INTA), Universidad de Chile, El Líbano 5524, Macul, Santiago, Chile. ${ }^{2}$ Division of Occupational and Environmental Medicine, Lund University, Lund, Sweden. ${ }^{3}$ Institutet of Environmental Medicine, Karolinska Institutet, Stockholm, Sweden. ${ }^{4}$ Unidad de Nutrición Humana, Instituto de Nutrición y Tecnología de los Alimentos Doctor Fernando Monckeberg Barros (INTA), Universidad de Chile, Santiago, Chile.

Received: 11 April 2017 Accepted: 18 July 2017

Published online: 24 July 2017

\section{References}

1. Lucock M. Folic acid: nutritional biochemistry, molecular biology, and role in disease processes. Mol Genet Metab. 2000;71:121-38.

2. Hertrampf E, Cortés F. National food-fortification program with folic acid in Chile. Food Nutr Bull. 2008;29:S231-7.

3. Ministry of Health (MINSAL), Chilean Government. Encuesta Nacional de Consumo Alimentario (ENCA 2009-2019). 2010. http://web.minsal.cl/enca.

4. Hirsch S, de la Maza P, Barrera G, Gattás V, Petermann M, Bunout D. The Chilean flour folic acid fortification program reduces serum homocysteine levels and masks vitamin B-12 deficiency in elderly people. J Nutr. 2002;132:289-91.

5. Sánchez H, Albala C, Hertrampf E, Verdugo R, Lavados M, Castillo JL, Lera L, Uauy R. Prevalence of vitamin B-12 deficiency in older adults. Rev Med Chil. 2010;138:44-52.

6. Pfeiffer C, Caudill S, Gunter E. Biochemical indicators of B vitamin status in the US population after folic acid fortification: results from the National Health and nutrition examination survey 1999-2001. Am J Clin Nutr. 2005;82:442-50

7. Hirsch S, Leiva L, de la Maza P, Gattas V, Barrera G, Hertrampf E, Bunout D. Effects of a nutritional supplement fortified with vitamin B-12 on well nourished, free-living elderly subjects. Int J Vitam Nutr Res. 2006;76:95-9.

8. Shane B. Folate and vitamin B12 metabolism: overview and interaction with riboflavin, vitamin B6, and polymorphisms. Food Nutr Bull. 2008; 29(2 Suppl):S5-16. 
9. Ministry of Health (MINSAL), Government of Chile. Encuesta Nacional de Salud (ENS 2009-2010). 2010.http://web.minsal.cl/portal/url/item/ bcb03d7bc28b64dfe040010165012d23.pdf.

10. Morris MS, Jacques PF, Rosenberg $I H$, Selhub J. Folate and vitamin B-12 status in relation to anemia, macrocytosis, and cognitive impairment in older Americans in the age of folic acid fortification. Am J Clin Nutr. 2007:85:193-200

11. Brito A, Verdugo R, Hertrampf E, Miller JW, Green R, Fedosov SN, ShahabFerdows S, Sanchez H, Albala C, Castillo JL, Matamala JM, Uauy R, Allen LH. Vitamin B-12 treatment of asymptomatic, deficient, elderly Chileans improves conductivity in myelinated peripheral nerves, but high serum folate impairs vitamin B-12 status response assessed by the combined indicator of vitamin B-12 status. Am J Clin Nutr. 2016;103:250-7.

12. Hernando-Herraez I, Heyn H, Fernandez-Callejo M, Vidal E, Fernandez-Bellon H, Prado-Martinez J, Sharp AJ, Esteller M, Marques-Bonet T. The interplay between DNA methylation and sequence divergence in recent human evolution. Nucleic Acids Res. 2015:43:8204-14.

13. Mitchell C, Schneper LM, Notterman DA. DNA methylation, early life environment, and health outcomes. Pediatr Res. 2016;79:212-9. doi:10. 1038/pr.2015.193. Epub 2015 Oct 14.13.

14. Khan S, Shukla S, Sinha S, Meeran SM. Epigenetic targets in cancer and aging: dietary and therapeutic interventions. Expert Opin Ther Targets. 2016;20:689-703.

15. Warton K, Mahon K, Samimi G. Methylated circulating tumor DNA in blood: power in cancer prognosis and response. Endocr Relat Cancer. 2016;13:ERC-15-0369.

16. Xue M, Lai SC, Wang LJ. Non-invasive DNA methylation biomarkers in colorectal cancer: a systematic review. J Dig Dis. 2015 Nov 13; doi:10. 1111/1751-2980.12299. [Epub ahead of print]

17. Institute of Medicine (US): Dietary Reference Intakes for Thiamin, Riboflavin, Niacin, Vitamin B6, Folate, Vitamin B12, Pantothenic Acid, Biotin, and Choline. A Report of the Standing Committee on the Scientific Evaluation of Dietary Reference Intakes and its Panel on Folate, Other B Vitamins, and Choline and Subcommittee on Upper Reference Levels of Nutrients, Food and Nutrition Board, Washington (DC) National Academies Press; 1998.

18. Baccarelli A, Wright RO, Bollati V, Tarantini L, Litonjua AA, Suh HH, Zanobetti A, Sparrow D, Vokonas PS, Schwartz J. Rapid DNA methylation changes after cxposure to traffic particles. Am J Respir Crit Care Med. 2009;179:572-8.

19. Zhao CQ, Young MR, Diwan BA, Cooga TP, Waalkes MP. Association of arsenic-induced malignant transformation with DNA hypomethylation and aberrant gene expression. Medical Sciences. 1997;94:10907-12.

20. Hu ZY, Tang LD, Zhou Q, Xiao L, Cao Y. Aberrant DNA methylation in hepatocellular carcinoma. Tumor Biol. 2015;36:1487-91. doi:10.1007/s13277014-2632-3. Epub 2015 Jan 17

21. Wu YC, Lv P, Han J, Yu JL, Zhu X, Hong LL, Zhu WY, Yu QM, Wang XB, Li P, Ling ZQ. Enhanced serum methylated p16 DNAs is associated with the progression of gastric cancer. Int J Clin Exp Pathol. 2014;7:1553-62. eCollection 2014

22. Kuan JC, Wu CC, Sun CA, Chu CM, Lin FG, Hsu CH, Kan PC, Lin SC, Yang T, Chou Y-C. DNA Methylation combinations in adjacent normal colon tissue predict cancer recurrence: evidence from a clinical cohort study. PLoS One. 2015;10(3):e0123396. doi:10.1371/journal.pone.0123396. eCollection 2015

23. Rasmussen SL, Krarup HB, Sunesen KG, Pedersen IS, Madsen PH, ThorlaciusUssing O. Hypermethylated DNA as a biomarker for colorectal cancer: a systematic review. Color Dis. 2016;18(6):549-61. doi:10.1111/codi.13336.

24. Kotake $Y$, Naemura M, Murasaki C, Inoue $Y$, Okamoto H. Transcriptional regulation of the p16 tumor suppressor gene. Anticancer Res. 2015:35:4397-401.

25. Waki T, Tamura G, Tsuchiya T, Sato K, Nishizuka S, Motoyama T. Promoter methylation status of e-cadherin, hMLH1, and p16 genes in nonneoplastic gastric epithelia. Am J Pathol. 2002;161:399-403.

26. Imai $\mathrm{K}$, Yamamoto H. Carcinogenesis and microsatellite instability: the interrelationship between genetics and epigenetics. Carcinogenesis. 2008;29:673-80.

27. Gelsomino F, Barbolini M, Spallanzani A, Pugliese G, Cascinu S. The evolving role of microsatellite instability in colorectal cancer: a review. Cancer Treat Rev. 2016;51:19-26. doi:10.1016/j.ctrv.2016.10.005. Epub 2016 Oct 27

28. Li Y, Lyu Z, Zhao L, Cheng H, Zhu D, Gao Y, Shang X, Shi H. Prognostic value of MGMT methylation in colorectal cancer: a meta-analysis and literature review. Tumor Biol. 2015;36:1595-601.
29. Hirsch S, Sanchez H, Albala C, De la Maza MP, Barrera G, Leiva L, Bunout D. Colon cancer in Chile before and after the start of the flour fortification program with folic acid. Eur J Gastroenterol Hepatol. 2009;21:436-9. doi:10.1097/MEG.0b013e328306ccdb.

30. Sanchez H, Albala C, Lera L, Dangour AD, Uauy R. Effectiveness of the National Program of complementary feeding for older adults in Chile on vitamin B12 status in older adults; secondary outcome analysis from the CENEX study (ISRCTN48153354). Nutr J. 2013;12:124. http://www.nutritionj. com/content/12/1/124

31. Ministry of Health, Chile, Statiscian Department: PACAM Report. 2010. http:// web.minsal.cl/portal/url/item/caa1783ed97a1425e0400101640109f9.pdf.

32. Quiroga P, Albala C, Klaasen G. Validation of a screening test for age associated cognitive impairment, in Chile. Rev Méd Chile. 2004;132:467-78.

33. Pedersen TL, Keyes WR, Shahab-Ferdows S, Allen LH, Newman JW. Methylmalonic acid quantification in low serum volumes by UPLC-MS/MS. J Chromatogr B Anal Technol Biomed Life Sci. 2011;879:1502-6.

34. Hossain MB, Vahter M, Concha G, Broberg K. Low-level environmental cadmium exposure is associated with DNA hypomethylation in Argentinean women. Environ Health Perspect. 2012a;120:879-84.

35. Hossain MB, Vahter M, Concha G, Broberg K. Environmental arsenic exposure and DNA methylation of the tumor suppressor gene $p 16$ and the DNA repair gene MLH1: effect of arsenic metabolism and genotype. Metallomics. 2012b;4:1167-75.

36. Harris LC, Remack JS, Brent TP. In vitro methylation of the human O6methylguanine-DNA methyltransferase promoter reduces transcription. Biochim Biophys Acta. 1994;1217:141-6.

37. Nakagawachi T, Soejima H, Urano T, Zhao W, Higashimoto $K$, Satoh $Y$, Matsukura S, Kudo S, Kitajima Y, Harada H, Furukawa K, Matsuzaki H, Emi M, Nakabeppu Y, Miyazaki K, Sekiguchi M, Mukai T. Silencing effect of CpG island hypermethylation and histone modifications on O6-methylguanineDNA methyltransferase (MGMT) gene expression in human cancer. Oncogene. 2003;22:8835-44

38. Warnecke PM, Stirzaker C, Melki JR, Millar DS, Paul CL, Clark CJ. Detection and measurement of PCR bias in quantitative methylation analysis of bisulphite-treated DNA. Nucleic Acids Res. 1997;25:4422-6.

39. Kitkumthorn $N$, Tuangsintanakul $T$, Rattanatanyong $P$, Tiwawech $D$, Mutirangura A. LINE-1 methylation in the peripheral blood mononuclear cells of cancer patients. Clin Chim Acta. 2012;18(413):869-74.

40. Ehrlich M. Expression of various genes is controlled by DNA methylation during mammalian development. J Cell Biochem. 2003;88:899-910.

41. Nexo E, Hoffmann-Lücke E. Holotranscobalamin, a marker of vitamin B-12 status: analytical aspects and clinical utility. Am J Clin Nutr. 2011;94:359S-65S.

42. Hannibal L, Lysne V, Bjørke-Monse A-L, Behringer S, Grünert SC, Spiekerkoette U, Jacobsen DW, Blom HJ. Biomarkers and algorithms for the diagnosis of vitamin B12 deficiency. Front Mol Biosci. 2016;3:27. doi.org/10.3389/fmolb.2016.00027

43. Willinek WA, Ludwig M, Lennarz M, Höller T, Stumpe KO. High-normal serum homocysteine concentrations are associated with an increased risk of early atherosclerotic carotid artery wall lesions in healthy subjects. J Hypertens. 2000; 18:425-30.

44. Zhou YH, Tang JY, Wu MJ, Lu J, Wei X, Qin YY, Wang C, Xu JF, He J. Effect of folic acid supplementation on cardiovascular outcomes: a systematic review and meta-analysis. PLoS One. 2011;6(9):e25142. doi:10.1371/journal. pone.0025142.

45. Ebbing $\mathrm{M}$, Bønaa $\mathrm{KH}$, Nygård $\mathrm{O}$, Arnesen $\mathrm{E}$, Ueland PM, Nordrehaug JE, Rasmussen K, Njølstad I, Refsum H, Nilsen DW, Tverdal A, Meyer K, Vollset SE. Cancer incidence and mortality after treatment with folic acid and vitamin B12. JAMA. 2009;302:2119-26.

46. Mason JB, Dickstein A, Jacques PF, Haggarty P, Selhub J, Dallal G, Rosenberg IH. A temporal association between folic acid fortification and an increase in colorectal cancer rates may be illuminating important biological principles: a hypothesis. Cancer Epidemiol Biomark Prev. 2007;16:1325-9.

47. Price AJ, Travis RC, Appleby PN, Albanes D, Barricarte Gurrea A, Bjørge T, Bueno-de-Mesquita HB, Chen C, Donovan J, Gislefoss R, Goodman G, Gunter M, Hamdy FC, Johansson M, King IB, Kühn T, Männistö S, Martin RM, Meyer K, Neal DE, Neuhouser ML, Nygård O, Stattin P, Tell GS, Trichopoulou A, Tumino R, Ueland PM, Ulvik A, de Vogel S, Vollset SE, Weinstein SJ, Key TJ, Allen NE. Endogenous hormones, nutritional biomarkers, and prostate cancer collaborative group. Eur Urol. 2016;70:941-51. doi:10.1016/j.eururo.2016.03.029.

48. Zschäbitz S, Cheng TY, Neuhouser ML, Zheng Y, Ray RM, Miller JW, Song X, Maneval DR, Beresford SA, Lane D, Shikany JM, Ulrich CM. B vitamin intakes 
and incidence of colorectal cancer: results from the Women's Health Initiative observational study cohort. Am J Clin Nutr. 2013;97:332-43.

49. Van Guelpen B, Hultdin J, Johansson I, Hallmans G, Stenling R, Riboli E, Winkvist A, Palmavist R. Low folate levels may protect against colorectal cancer. Gut. 2006;55:1461-6.

50. Hu J, Juan W, Sahyoun NR. Intake and biomarkers of folate and risk of cancer morbidity in older adults, NHANES 1999-2002 with Medicare linkage. PLoS One. 2016 Feb 10;11(2):e0148697. doi:10.1371/journal.pone.0148697.

51. Akhavan-Niaki H, Samadani AA. DNA methylation and cancer development: molecular mechanism. Cell Biochem Biophys. 2013;67:501-13.

52. Shan M, Yin H, Li J, Li X, Wang D, Su Y, Niu M, Zhong Z, Wang J, Zhang X, Kang W, Pang D. Detection of aberrant methylation of a six-gene panel in serum DNA for diagnosis of breast cancer. Oncotarget. 2016;7:18485-94.

53. Qi D, Li J, Jiang M, Liu C, Hu Y, Li M, Su J, Que B, Ji W. The relationship between promoter methylation of p16 gene and bladder cancer risk: a meta-analysis. Int J Clin Exp Med. 2015;8:20701-11.

54. Tao K, Wu C, Wu K, Li W, Han G, Shuai X, Wang G. Quantitative analysis of promoter methylation of the EDNRB gene in gastric cancer. Med Oncol. 2012:29:107-12.

55. Kok DE, Dhonukshe-Rutten RA, Lute C, Heil SG, Uitterlinden AG, van der Velde N, van Meurs JB, van Schoor NM, Hooiveld GJ, de Groot LC, Kampman E, Steegenga WT. The effects of long-term daily folic acid and vitamin B12 supplementation on genome-wide DNA methylation in elderly subjects. Clin Epigenetics. 2015;7:121. doi:10.1186/s13148-0150154-5. eCollection 2015

56. Chen $\mathrm{K}$, Zhao BS, He C. Nucleic acid modifications in regulation of gene expression. Cell Chem Biol. 2016;21(23):74-85.

\section{Submit your next manuscript to BioMed Central and we will help you at every step:}

- We accept pre-submission inquiries

- Our selector tool helps you to find the most relevant journal

- We provide round the clock customer support

- Convenient online submission

- Thorough peer review

- Inclusion in PubMed and all major indexing services

- Maximum visibility for your research

Submit your manuscript at www.biomedcentral.com/submit 